\title{
Intake and total apparent digestibility in lambs fed six maize varieties in the Brazilian Semiarid
}

\author{
Rafael Dantas dos Santos ${ }^{1}$, Luiz Gustavo Ribeiro Pereira², André Luis Alves Neves², \\ Gherman Garcia Leal de Araújo ${ }^{1}$, Alex Santos Lustosa de Aragão ${ }^{3}$, Mário Luiz Chizzotti ${ }^{4}$
}

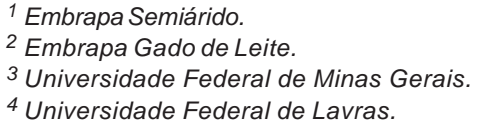

\begin{abstract}
The objective of this study was to evaluate the daily intake and total apparent digestibility of dry matter, organic matter, crude protein, gross energy, ether extract, neutral detergent fiber, acid detergent fiber, total and non-fibrous carbohydrates, total digestible nutrients, energy intake and nitrogen balance of silages of six maize varieties with early or super early cycles recommended to Northeast Brazil. Twenty-four male castrated lambs were lodged in metabolic cages. A completely randomized design with six treatments and four replications was used, with means compared by Tukey test at $5 \%$. There were no differences among varieties for any of the evaluated variables regarding intake and apparent digestibility. Concerning the intake of digestible energy, metabolizable energy and the ratio content of digestible and metabolizable energy, significant differences were observed between varieties and BRS Assum Preto showed highest values of metabolizable energy (2.650,8 kcal/day). All of the treatments presented positive nitrogen balance and did not differ among themselves. The varieties asessed can be an additional option to the semiarid regions in Brazil.
\end{abstract}

Key Words: feeding, nutrition, sheep, ruminants, supplementation, Zea mays

\section{Introduction}

Corn crops have shown an important role in agricultural income, human and animal feeding the in Brazilian Northeast. However, the productivity of maize has decreased and this situation has been caused by unstable rainfall, low technology level adopted by producers and daily temperatures surpassing $40^{\circ} \mathrm{C}$ (Carvalho \& Souza, 2007).

This local reality has created native vegetation dependence and low performance of their herds. To solve these problems it is necessary good management and use of native forages conserved and adapted to environment like hay or silage. These steps could even improve animal production rates.

Traditionally, maize plant has been used for silage because it presents high dry matter production and appropriate chemical composition, such as dry matter content in the harvest moment, minimum of 3\% soluble carbohydrate in the original matter, low buffering, and provides a good microbial fermentation (Ferrari Júnior et al., 2005; Pereira et al., 2004).

Regional information lack about nutritional value of the genetic materials has been a great obstacle to the agribusiness of corn, since there are some difficulties to choose maize hybrids for silage production in semiarid zones. Thenceforth, chemical composition, intake, digestion, absorption and animal metabolism have been considered at the nutritional value evaluation of forages (Rodriguez et al., 2006).

The objectives of this study were to evaluate voluntary intake and total apparent digestibility of six maize varieties with early or super early cycles in lambs.

\section{Material and Methods}

The experiment was conducted at Embrapa Semiarido,

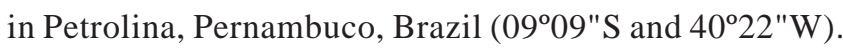
The average regional precipitation was $570 \mathrm{~mm}$ per year, altitude of $365.5 \mathrm{~m}$ and annual average temperatures of $33.46^{\circ} \mathrm{C}$ (maximum) and $20.7^{\circ} \mathrm{C}$ (minimum), respectively. Climate conditions during roughage production period were considered normal for the annual period in this region (Table 1).

Six maize varieties (BRS Caatingueiro (CTG), BRS Assum Preto (APR), BR 5033 Asa Branca (5033), BR 5028 São Francisco (5028), Gurutuba (GTB) and BRS 4103 (4103) recommended to semiarid region were evaluated (Table 2). A completely randomized design with six treatments (corn varieties) and four replications was used. 
Table 1 - Meteorological data during experimental period

\begin{tabular}{|c|c|c|c|c|c|c|c|}
\hline \multirow[t]{2}{*}{ Month/Year } & \multirow[t]{2}{*}{ Days $^{1}$} & \multirow[t]{2}{*}{ Rain $(\mathrm{mm})^{2}$} & \multicolumn{3}{|c|}{ Temperature $\left({ }^{\circ} \mathrm{C}\right)$} & \multirow[t]{2}{*}{ Evaporation (mm) } & \multirow[t]{2}{*}{$\mathrm{RH}(\%)^{3}$} \\
\hline & & & Max. & Min. & Mean & & \\
\hline April/2007 & 06 & 12.2 & 33.8 & 21.6 & 26.9 & 7.2 & 60 \\
\hline June/2007 & 06 & 6.8 & 31.1 & 19.4 & 24.8 & 7.2 & 61 \\
\hline July/2007 & 05 & 9.2 & 30.6 & 19.1 & 24.1 & 7.1 & 63 \\
\hline August/2007 & 04 & 6.3 & 31.3 & 18.5 & 24.4 & 8.2 & 55 \\
\hline
\end{tabular}

${ }^{1}$ Rainfall in days; ${ }^{2}$ Rainfall in millimeters; ${ }^{3}$ Relative humidity in the air (\%).

Table 2 - Features of the corn varieties used

\begin{tabular}{lccc}
\hline Varieties & Cycle & Utilization & Grain traits \\
\hline BRS Caatingueiro & Super early & Grain & Semi hard \\
BRS Assum Preto & Super early & Grain & Semi hard \\
BR 5033 - Asa Branca & Early & Grain & Semi hard \\
BR 5028 - São Francisco & Early & Grain & Semi dented \\
Gurutuba & Super early & Grain & Semi hard \\
BRS 4103 & Early & Grain & Semi hard \\
\hline
\end{tabular}

At the beginning, the area was prepared for planting through plowing, breaking up and harrowing the soil and leveling, as well. Furrows were opened spaced each other about $1 \mathrm{~m}$ before establishment of the corn tillage.

Soil analyses revealed some chemical traits such as: Water $\mathrm{pH}=5.80 ; \mathrm{P}=5.10 \mathrm{mg} / \mathrm{dm}^{3} ; \mathrm{K}=0.60 \mathrm{cmol}_{\mathrm{c}} / \mathrm{dm}^{3}$; $\mathrm{Al}=0.05 \mathrm{cmol}_{\mathrm{C}} / \mathrm{dm}^{3} ; \mathrm{H}+\mathrm{Al}=1.98 \mathrm{cmol}_{\mathrm{c}} / \mathrm{dm}^{3} ; \mathrm{Ca}=$ $1.50 \mathrm{cmol}_{\mathrm{C}} / \mathrm{dm}^{3} ; \mathrm{Mg}=0.70 \mathrm{cmol}_{\mathrm{c}} / \mathrm{dm}^{3} ;$ M.O. $=13.03 \mathrm{~g} / \mathrm{kg}$; $\mathrm{V} \%=59.0$. Fertilization was done through soil analyses, and during sowing fertilization $650 \mathrm{Kg} /$ hectare of the formula 4-20-20 were used. After this, two cover fertilizations were held with $60 \mathrm{~kg}$ nitrogen/hectare on $30^{\text {th }}$ and $45^{\text {th }}$ days after emergence and two applications of insecticides for pest control. Twenty-two days after emergence, one thinning down was done and population was established at around 55.000 plants/ha.

When grains presented hard farinaceous stage, plants were harvested at 81 days after planting, then stacking and chopping were performed through silage cutter stationary machine adjusted to produce particles of about $2 \mathrm{~cm}$. Materials were ensiled into 18 concrete silos (capacity of 250 liters), internally coated with tarpaulin plastic. Each concrete silo was compacted by trampling and sealing was done with plastic tarpaulin and tapes, whereas opening was done 90 days later.

Twenty-four castrated and unknown breed lambs with body weight (BW) of $19 \mathrm{~kg} \pm 1.6 \mathrm{~kg}$ were used. The diet including corn silages as single exclusive roughage was offered twice daily (7h30min and 16h30min) and intake was adjusted to ensure orts about $15 \%$ of as fed matter. Water and mineral mixture were available to lambs all the time.
The experimental period took 5 days for sample collection and 17 days for adaptation of animals to feeding, cages and collection bags. Weightings were done at the beginning and end of each one.

Silage supply, orts from feed box and total production of feces were quantified during the experimental period; daily samples of around $300 \mathrm{~g} /$ treatment/day were collected from each material offered. Orts were collected in the morning, weighed and packed in plastics bags, identified and frozen to be analyzed afterwards. About $20 \%$ of feces were weighed and collected once daily from the total measurements.

$100 \mathrm{ml}$ of hydrochloric acid with $2 \mathrm{~N}$ concentration were put into samples to prevent fermentation, degradation and losses of nitrogen. Sampling around $10 \%$ from the total measurements of urine were obtained only in the morning and frozen for posterior analyses. A composite sample per animal was originated from daily samples.

Feed, orts and fecal samples were analyzed for dry matter (DM), organic matter (OM), crude protein (CP), crude energy (CE) and ether extract (EE) in duplicates (Silva \& Queiroz, 2002) and also for neutral detergent fiber (NDF) and acid detergent fiber (ADF) (Van Soest et al., 1991). Gross energy and total nitrogen were determined in urine samples according to Silva \& Queiroz (2002). All crude energy analyses were done through bomb calorimeter PARR $^{\circledR}$ (AOAC, 1980).

Apparent digestibility of nutrients was carried out following technique described by Silva \& Leão (1979). Total carbohydrates (TC) and non-fibrous carbohydrates (NFC) values were calculated as proposed by Sniffen et al. (1992): $\mathrm{TC}=100-(\mathrm{CP} \%+\mathrm{EE} \%+\mathrm{MM} \%)$ and $\mathrm{NFC}=100-(\mathrm{CP} \%+$ $\mathrm{EE} \%+\mathrm{MM} \%+\mathrm{NDF} \%)$.

Total digestible nutrients (TDN) were calculated by using the equation NDT $=$ digestible $\mathrm{CP}+2.25 \times$ digestible $\mathrm{EE}+$ digestible NDF + digestible NFC, according to the NRC(2001).

Digestible energy (DE) values were obtained by the difference between gross energy intake and gross energy excreted in feces. Metabolizable energy (ME) represents digestible energy minus energy losses in urine and gases 
(mainly gas methane). Methane losses were calculated, when maintenance situation was considered, by using the model proposed by Blaxter \& Clapperton (1965), where $\mathrm{Cm}=3.67+0.062 \mathrm{D}$, where, $\mathrm{Cm}=$ methane production (Kcal/100 Kcal of ingested energy) and D = apparent digestibility from gross energy into dry matter.

Variables were tested for checking of normal distribution occurrence before analysis of variance. Means were compared by Tukey test at $5 \%$ probability $(\mathrm{P}<0.05)$. Statistical analyses were done in the SAS program (SAS, 2002).

\section{Results and Discussion}

Results obtained from six varieties of corn silages were similar to the ones found in the literature (Table 3).

Chemical composition values were similar to those mentioned by Valadares Filho et al. (2006) in the Tabela Brasileira de Composição de Alimentos (Brazilian Chart of Food Composition), who reported the following numbers $30.9 \%, 94.7 \%$, 7.2\%, 55.4\%, 30.6\%, 84.8\%, 34.3\%, 3.16\%, $4.320 \mathrm{kcal} / \mathrm{kg}$ and $64.2 \%$ for DM, OM, CP, NDF, ADF, TC, NFC, EE, GE and TDN, respectively, although nowadays these varieties are not being used for ensilage production.

Dry matter values were similar to results found by Senger et al. (2005) (24.1\%) and Pereira et al. (2007) (25.8\%), but lower results were obtained by Jaremtchuk et al. (2005) and Rosa et al. (2004) when early cycle genotypes were evaluated for them. All treatments, except for the early cycle variety named BR 5028 - São Francisco, presented CP contents higher than $6 \%$, since this is considered a minimum level so that rumen bacteria might be developing properly (Van Soest, 1994). In addition, these values are according to assays performed in the Brazilian semiarid region. These numbers are also similar to data reported by Paziani et al.(2009) and Pereira et al. (2007), who showed an average percentage of CP of 6.7 and $6.4 \%$, respectively. Miron et al. (2007) have also observed DM values of 34.1\% and $6.2 \%$ of CP, evaluating corn silage in dry zones of the Middle East.

Gross energy contents were close between varieties, and these values were also similar to results found by De Boever et al. (1997), who reported average numbers of $4.628 \mathrm{Kcal} / \mathrm{kg}$. Kirkland \& Patterson (2006) observed results of $4.376 \mathrm{Kcal} / \mathrm{kg}$ in United Kingdom, and Nishida et al. (2007) also found results similar to this experiment $(4.619 \mathrm{kcal} / \mathrm{kg})$ when genotypes of corn silages were studied in Japan.

There were no differences $(\mathrm{P}>0.05)$ for nutrients intake or fibrous fractions (Table 4).

The amount of leftovers in the trough was predictable: approximately $15 \%$, and it confirmed the occurrence of normal selection of the material, with greater share of stem parts and greater retention of leaf parts and ear.

Dry matter, organic matter, crude protein, total carbohydrates and neutral detergent fiber intakes were lower than the results obtained by Moreira et al. (2001), who observed intake of 752.6 g/day of DM, $694.7 \mathrm{~g} /$ day of OM, $43.1 \mathrm{~g} /$ day of CP, $640.2 \mathrm{~g} /$ day of TC and $447.8 \mathrm{~g} /$ day of NDF. However, these reported data were lower to ether extract and total digestible intake, with values of $5.9 \mathrm{~g} /$ day of EE and $359.0 \mathrm{~g}$ /day of TDN, respectively.

Intake of total digestible nutrients in g/day obtained in this research ranged from 373.2 to $481.2 \mathrm{~g} /$ day. These levels are according to NRC's (2007) recommendations, where minimum requirements of $350 \mathrm{~g}$ /day for animals with this body weight range and gains of $100 \mathrm{~g} /$ day can be found.

Results found for intake in $\mathrm{g} / \mathrm{kg}^{0.75} /$ day of DM were higher than ones obtained by Freitas et al. (2003), when they evaluated HT01, HT47C, HT129, AG5011 and BR3123 corn genotypes and reported average intake of $60.7 \mathrm{~g} / \mathrm{kg}^{0.75} /$ day. Ribas et al. (2007) described results similar to those found in this study when voluntary intake of dry matter and crude protein from four hybrid corn silage (SHS 4040, QPM 129, AG 1051 and BRS 3060) were evaluated in lambs. These authors presented average

Table 3 - Chemical-bromathological composition of silages of the corn varieties evaluated

\begin{tabular}{|c|c|c|c|c|c|c|}
\hline \multirow[t]{2}{*}{ Nutrient } & \multicolumn{6}{|c|}{ Varieties $^{1}$} \\
\hline & 5033 & 5028 & 4103 & APR & GTB & CTG \\
\hline Total dry matter & 23.4 & 28.1 & 26.2 & 25.6 & 26.2 & 29.9 \\
\hline Organic matter & 95.1 & 95.3 & 95.6 & 94.5 & 94.3 & 94.6 \\
\hline Crude protein & 6.1 & 5.5 & 6.2 & 6.4 & 6.9 & 6.4 \\
\hline Neutral detergent fiber & 51.3 & 51.7 & 45.2 & 48.1 & 45.9 & 48.1 \\
\hline Acid detergent fiber & 26.0 & 26.5 & 23.3 & 23.6 & 23.4 & 24.0 \\
\hline Total carbohydrates & 87.6 & 88.2 & 88.0 & 86.5 & 85.9 & 86.8 \\
\hline Non-fibrous carbohydrates & 36.3 & 36.5 & 42.7 & 38.4 & 40.0 & 38.7 \\
\hline Ether extract & 3.2 & 3.4 & 3.3 & 3.3 & 3.4 & 3.3 \\
\hline Gross energy & 4.339 .4 & 4.185 .9 & 4.176 .8 & 4.437 .8 & 4.199 .1 & 4.233 .8 \\
\hline Total digestible nutrients & 61.4 & 65.2 & 54.2 & 61.7 & 63.8 & 63.9 \\
\hline
\end{tabular}


Table 4 - Nutrients and fibrous fractions intake from the six varieties of corn silage

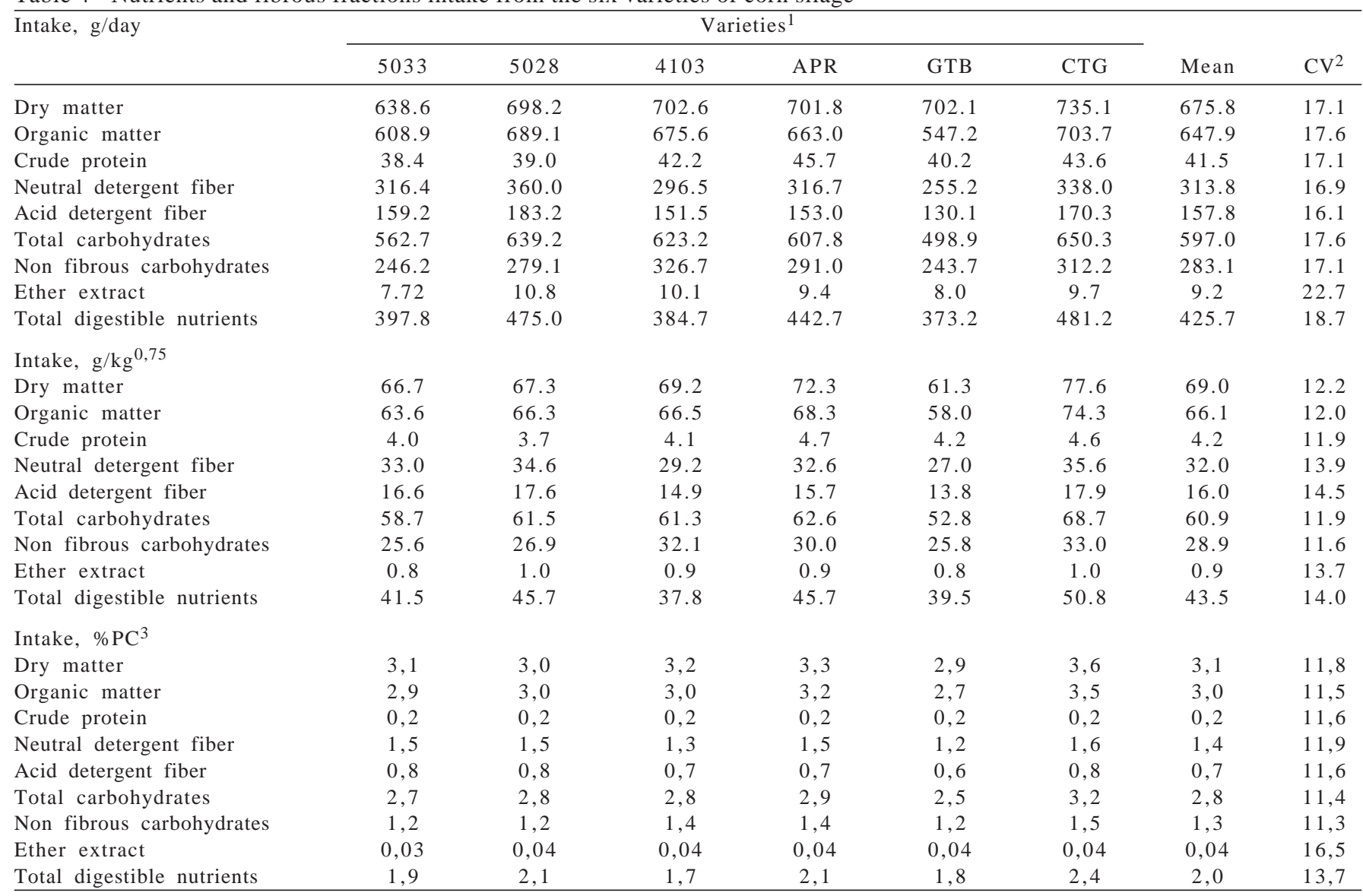

15033 - BR 5033 Asa Branca; 5028 - BR 5028 São Francisco; 4103 - BRS 4103; APR - BRS Assum Preto; GTB - Gurutuba; CTG - BRS Caatingueiro.

${ }^{2} \mathrm{CV}$ - Coefficient of variation in \%.

3 \%PC - Percentage of body weight.

values for DM and CP intakes of $64.9 \mathrm{~g} / \mathrm{kg}^{0.75} /$ day and $4.9 \mathrm{~g} / \mathrm{kg}^{0.75} /$ day, respectively.

Results lower than those found in this experiment were obtained by Vranic et al. (2008), when they observed intake of $49.8 \mathrm{~g} / \mathrm{kg}^{0.75} /$ day of OM and $31.3 \mathrm{~g} / \mathrm{kg}^{0.75} /$ day of NDF, in lambs fed corn silage.

Intakes of neutral detergent fiber, acid detergent fiber and ether extract (in $\mathrm{g} / \mathrm{kg}^{0.75} /$ day) were studied by Mizubuti et al. (2002) when they observed higher values than the ones found in this assay $\left(41.3,36.5\right.$ and $3.6 \mathrm{~g} / \mathrm{kg}^{0.75} / \mathrm{day}$, respectively), when corn, sorghum and sunflower silages were evaluated on feeding of lambs. Similarity of results between recommended varieties to semiarid and ones currently used to silage production in other regions was observed.

Measuring the intake of fibrous fractions' intake measurement is very important, since fiber can carry out several metabolic and physiological effects into animal organism. High contents of this fraction could cause energy dilution of the diet and increase compensatory intake so that the energetic levels recommended for development and production may be reached (Van Soest et al., 1991).

Intake of fractions of nutrients and fiber were statistically similar ( $\mathrm{P}>0.05)$, in body weight percentage. Average of 3.1\% BW to DM intake was similar to that found by Bueno et al. (2004), where they observed values of 3.14\% BW when corn silage was fed to lambs in the south region of the São Paulo State.

There was no variety effect $(\mathrm{P}>0.05)$ on dry matter apparent digestibility, organic matter, crude protein, neutral detergent fiber, acid detergent fiber, total carbohydrates, non fibrous carbohydrates, ether extract or gross energy (Table 5).

Aksu et al. (2004) described average values for dry matter apparent digestibility, organic matter, crude protein, neutral detergent fiber and acid detergent fiber of 59.3, 64.1, 48.3, 55.3 and 63.3\%, respectively, when studying corn silage on Morkaraman lambs feeding, with around $31 \mathrm{~kg} \mathrm{BW}$, in the semiarid regions of Turkey. It is important to remark that values observed by these authors were lower than those obtained in the current research. 
Digestibility coefficient of the fibrous fractions (NDF an ADF) are according to results by Mizubuti et al. (2002). They reported similar values for digestibility of fibrous fractions (50.8\% for NDF and $64.4 \%$ for ADF), when lambs with average body weight of $35 \mathrm{~kg}$ were used.

Apparent gross energy results from the present study were similar to those obtained by Ribas et al. (2007) (66.6\%), who evaluated apparent digestibility from four corn hybrids in lambs. Yet results from this experiment were higher than the ones described by Freitas et al. (2003), who evaluated five corn hybrids in lambs and obtained average values of 61.1\%. Valadares Filho et al. (2006) also reported lower results than those obtained im this assay (57.4\%) in the Tabela Brasileira de Composição de Alimentos.

Regarding energy balance from the searched silages, differences were observed $(\mathrm{P}<0.05)$ over all variables, except for gross energy voluntary intake $(\mathrm{P}>0.05$ ) (Table 6$)$.

Gross energy intake, in $\mathrm{kcal} / \mathrm{kg}^{0.75} / \mathrm{day}$, was similar to the ones presented by Freitas et al. (2003) and Ribas et al. (2007), with $273.1 \mathrm{kcal} / \mathrm{kg}^{0.75} /$ day and $280.4 \mathrm{kcal} / \mathrm{kg}^{0.75} /$ day, respectively. But, the same authors observed lower values for digestible energy ( $\mathrm{kcal} / \mathrm{kg}^{0.75} /$ day), and Freitas et al.
(2003) reported average ranging from 149.3 to $190.3 \mathrm{kcal} / \mathrm{kg}^{0.75} /$ day and Ribas et al. (2007), from 173.8 to $195.8 \mathrm{kcal} / \mathrm{kg}^{0.75} /$ day.

Metabolizable energy intakes ranged from 1.510 .5 to $2.650 .8 \mathrm{kcal} /$ day and were higher than the ones recommended by the NRC (2007), whose requirements are around $590 \mathrm{kcal} /$ day for lambs with $20 \mathrm{~kg}$ of BW and daily gains of $100 \mathrm{~g}$. Super early BRS Assum Preto variety presented values for digestible energy intake and metabolizable per $\mathrm{kg}^{0.75}$ /day higher than Gurutuba and BRS Caatingueiro. This probably happened because that material presented high gross energy contents in association with high apparent digestibility from the gross energy. There was no negative balance, because in all evaluated silages appropriate levels of metabolizable energy were provided to the animals. This fact can be corroborated by Freitas et al. (2003) and Ribas et al. (2007).

By considering the ratio between digestible and metabolizable energy intakes and dry matter intake(DEI/DMI and MEI/DMI), lower values for BRS Caatingueiro were evidenced, compared with other varieties studied $(\mathrm{P}<0.05)$. Results obtained for dry matter intake from these varieties

Table 5 - Total apparent digestibility coefficient (\%) of the main nutrients and fibrous fractions from the six varieties of corn silages

\begin{tabular}{|c|c|c|c|c|c|c|c|c|}
\hline \multirow[t]{2}{*}{ Intake, g/day } & \multicolumn{6}{|c|}{ Varieties $^{1}$} & \multirow[b]{2}{*}{ Mean } & \multirow[b]{2}{*}{$\mathrm{CV}^{2}$} \\
\hline & 5033 & 5028 & 4103 & APR & GTB & CTG & & \\
\hline Dry matter & 62.2 & 65.6 & 61.6 & 64.0 & 65.1 & 65.5 & 64.0 & 8.8 \\
\hline Organic matter & 64.1 & 67.5 & 63.4 & 65.2 & 66.9 & 67.4 & 65.7 & 7.3 \\
\hline Crude protein & 51.5 & 51.3 & 48.6 & 55.3 & 57.7 & 54.4 & 53.1 & 19.0 \\
\hline Neutral detergent fiber & 52.6 & 58.2 & 41.9 & 50.4 & 52.6 & 53.6 & 51.5 & 7.8 \\
\hline Acid detergent fiber & 53.3 & 57.7 & 45.2 & 51.7 & 51.9 & 53.6 & 52.2 & 7.3 \\
\hline Total carbohydrates & 64.9 & 68.3 & 64.2 & 65.8 & 67.5 & 68.2 & 66.4 & 7.2 \\
\hline Non-fibrous carbohydrates & 80.5 & 81.2 & 84.3 & 82.3 & 83.1 & 83.9 & 82.5 & 4.2 \\
\hline Ether extract & 67.4 & 74.8 & 72.1 & 71.5 & 72.9 & 68.8 & 71.2 & 6.7 \\
\hline Gross energy & 65.2 & 67.0 & 62.9 & 67.4 & 65.9 & 68.4 & 66.1 & 7.1 \\
\hline
\end{tabular}

15033 - BR 5033 Asa Branca; 5028 - BR 5028 São Francisco; 4103 - BRS 4103; APR - BRS Assum Preto; GTB - Gurutuba; CTG - BRS Caatingueiro.

${ }^{2} \mathrm{CV}$ - Coefficient of variation, in \%.

Table 6 - Energy intake from six varieties of corn silages

\begin{tabular}{|c|c|c|c|c|c|c|c|c|}
\hline \multirow[t]{2}{*}{ Energy $^{2}$} & \multicolumn{6}{|c|}{ Varieties $^{1}$} & \multirow[b]{2}{*}{ Mean } & \multirow[b]{2}{*}{$\mathrm{CV}^{3}$} \\
\hline & 5033 & 5028 & 4103 & APR & GTB & CTG & & \\
\hline GEI & 2.841 .9 & 3.068 .6 & 2.913 .5 & 3.221 .6 & 2.463 .5 & 3.255 .0 & 2.960 .6 & 16.6 \\
\hline DEI & $2.359 .7 \mathrm{ab}$ & $2.883 .7 \mathrm{ab}$ & $2.533 .0 \mathrm{ab}$ & $3.125 .3 \mathrm{a}$ & $2.040 .5 b$ & $2.231 .1 \mathrm{ab}$ & 2.528 .9 & 18.2 \\
\hline DEI 0,75 & 245.5ab & 277.1ab & 249.8ab & $323.7 \mathrm{a}$ & 217.6b & 235.8b & 258.3 & 14.6 \\
\hline MEI & $1.816 .9 \mathrm{ab}$ & $2.351 .7 \mathrm{ab}$ & $1.967 .3 \mathrm{ab}$ & $2.650 .8 \mathrm{a}$ & $1.510 .5 b$ & $1.588 .4 \mathrm{~b}$ & 1980.9 & 23.2 \\
\hline MEI/DMI & $1.7 a b$ & $2.1 \mathrm{a}$ & 1.9ab & $2.4 \mathrm{a}$ & 1.6ab & $1.2 \mathrm{~b}$ & 1.8 & 20.7 \\
\hline
\end{tabular}

Means followed by different letters in the same row differ by Tukey's Test $(\mathrm{P}<0.05)$.

15033 - BR 5033 Asa Branca; 5028 - BR 5028 São Francisco; 4103 - BRS 4103; APR - BRS Assum Preto; GTB - Gurutuba; CTG - BRS Caatingueiro.

2 GEI - Gross energy intake in kcal/day; GEI ${ }^{0.75}$ - Gross energy intake in kcal/kg $\mathrm{kg}^{0.75} /$ day; DEI - Digestible energy intake in $\mathrm{kcal} / \mathrm{day}$; DEI ${ }^{0.75}$ - Gross energy intake in $\mathrm{kcal} / \mathrm{kg}^{0.75} / \mathrm{day}$; MEI - Metabolizable energy intake in kcal/day; MEI ${ }^{0.75}$ - Metabolizable energy intake in kcal/kg0.75/day DEI/DMI - Digestible energy intake per gram of DM ingested in kcalDE/gDM; CEM/CMS - Metabolizable energy intake per gram of DM ingested in kcalME/gDM.

${ }^{3} \mathrm{CV}$ - Coefficient of variation, in \%. 
in association with digestible and metabolizable energy intakes could explain the highest values for DEI/DMI and MEI/DMI. These ratios are important in the foods nutritive evaluation, since they are parameters of energy efficiency use. However, high efficiency ratios are only interesting when high dry matter intake can be reached, which was observed in this experiment through minimum requirements indicated by the NRC (2007) for lambs with this body weight range and daily gains of $100 \mathrm{~g}$. Such results might appoint the use of these silages as quality alternative roughage to the semiarid.

There were no differences for ingested nitrogen and fecal and urinary nitrogen excretions in grams per day or nitrogen balance $(\mathrm{P}>0.05)$ (Table 7).

Super early BRS Assum Preto and BRS Caatingueiro presented higher values of nitrogen absorbed per $\mathrm{kg}^{0.75}$ than BR5033 - Asa Branca. In the current experiment, all silages showed positive nitrogen balance. Freitas et al. (2003) and Ribas et al. (2007) found results higher than those obtained by this study ( 4.8 and $4.7 \mathrm{~g}$ /day of nitrogen absorbed, respectively).

Negative nitrogen balance of $0.28 \mathrm{~g} /$ day was observed by Vranic et al. (2008), who reported nitrogen intake of $9.4 \mathrm{~g} /$ day and fecal and urinary nitrogen excretions of 5.8 and $3.9 \mathrm{~g} /$ day, respectively, which were lower than ones presented by this survey. As for $\mathrm{N}$ absorbed/ $\mathrm{N}$ intake ratio, Ribas et al. (2007) had similar results (32.2\% N absorbed/N intake). These authors even observed values close to those found by this experiment when they studied five corn genotypes, including one early cycle material.

Positive nitrogen balance observed in all treatments showed appropriate protein use, since probably there was no body reserve mobilization during the experimental period. Also, there were no protein losses during silage intake from the evaluated varieties, and these facts are very important to the semiarid, because soil and climate conditions and the regional production systems require optimization of forage use.

Table 7 - Nitrogen balance from the six varieties of corn silages

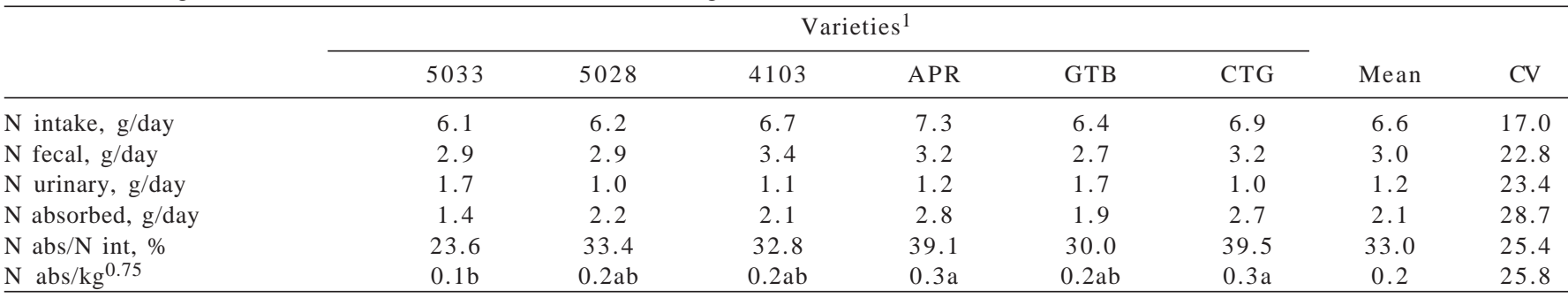

Means followed by different letters in the same row differ $(\mathrm{P}<0.05)$ by Tukey's test.

15033 - BR 5033 Asa Branca; 5028 - BR 5028 São Francisco; 4103 - BRS 4103; APR - BRS Assum Preto; GTB - Gurutuba; CTG - BRS Caatingueiro.

CV - Coefficient of variation, \%.

\section{Conclusions}

The six varieties of corn silages (BRS Caatingueiro (CTG), BRS Assum Preto (APR), BR5033 Asa Branca(5033), BR 5028 São Francisco (5028), Gurutuba (GTB) and BRS 4103 (4103)) evaluated present potential for ruminants' feeding in the Brazilian semiarid.

\section{References}

AKSU, T.; BAYTOK, E.; BOLAT, D.I. Effects of a bacterial silage inoculant on corn silage fermentation and nutrient digestibility. Small Ruminant Research, v.55, p.249-52, 2004.

ASSOCIATION OF OFFICIAL AGRICULTURE CHEMISTS AOAC. Official methods of analyses of the Association of Agriculture Chemists. 13.ed. Washington, D.C.: 1980. 1015p.

BLAXTER, K.L.; CLAPPERTON, J.L. Prediction of the amount of methane produced by ruminants. British Journal of Nutrition, v.19, n.4, p. 511-522, 1965.
BUENO, M.S.; FERRARI JÚNIOR, E.; POSSENTI, R.A. et al. Desempenho de cordeiros alimentados com silagem de girassol ou de milho com proporções crescentes de ração concentrada. Revista Brasileira de Zootecnia, v.33, n.6, p.1942-1948, 2004.

CARVALHO, H.W.L.; SOUZA, E.M. Ciclos de seleção de progênies de meios-irmãos do milho BR 5011 Sertanejo. Pesquisa Agropecuária Brasileira, v.42, n.6, p.803-809, 2007.

De BOEVER, J.L.; COTTYN, B.G.; De BRABANDER, D.L. et al. Prediction of the feeding value of maize silages by chemical parameters, in vitro digestibility and NIRS. Animal Feed Science Technology, v.66, p.211-222, 1997.

FERRARI JÚNIOR, E.; POSSENTI, R.A.; LIMA, M.L.P. et al. Características, composição química e qualidade de silagens de oito cultivares de milho. Boletim de Indústria Animal, v.62, n.1, p.19-27, 2005.

FREITAS, G.A.R.; COELHO, S.G.; GONÇALVES, L.C. et al. Consumo e digestibilidade aparente da matéria seca, proteína e energia bruta, e balanço de nitrogênio das silagens de cinco genótipos de milho. Arquivo Brasileiro de Medicina Veterinária e Zootecnia, v.55, n.4, p.443-449, 2003.

JAREMTCHUK, A.R.; JAREMTCHUK, C.C.; BAGLIOLI, B. et al. Características agronômicas e bromatológicas de vinte genótipos 
de milho (Zea mays L.) para silagem na região leste paranaense. Acta Scientiarum.Animal Sciences, v.27, n.2, p.181-188, 2005.

KIRKLAND, R.M.; PATTERSON, D.C. The effect of quality of grass and maize silage on the intake and performance of beef cattle. Livestock Science, v.100, p.179-188, 2006.

MIRON, J.; ZUCKERMAN, E.; ADIN, G. et al. Comparison of two forage sorghum varieties with corn and the effect of feeding their silages on eating behavior and lactation performance of dairy cows. Animal Feed Science and Technology, n.139, p.23-39, 2007.

MIZUBUTI, I.Y.; RIBEIRO, E.L.A.; ROCHA, M.A. et al. Consumo e digestibilidade aparente das silagens de milho (Zea mays L.), sorgo (Sorghum bicolor (L.) Moench) e girassol (Helianthus annuus L.). Revista Brasileira de Zootecnia, v.31, n.1, p.267-272, 2002.

MOREIRA, A.L.; PEREIRA, O.G.; GARCIA, R. et al. Consumo e digestibilidade aparente dos nutrientes da silagem de milho e dos fenos de alfafa e de capim-coastcross, em ovinos. Revista Brasileira de Zootecnia, v.30, n.3, p.1099-1105, 2001.

NATIONAL RESEARCH COUNCIL - NRC. Nutrient requirements of dairy cattle. 7.ed. Washington, D.C., 2001. 363p.

NATIONAL RESEARCH COUNCIL - NRC. Nutrient requirement of small ruminants. Washington, D.C., 2007. 362p.

NISHIDA, T.; ERUDEN, B.; HOSODA, K. et al. Digestibility, methane production and chewing activity of steers fed wholecrop round bale corn silage preserved at three maturities. Animal Feed Science and Technology, v.135, p.42-51, 2007.

PAZIANI, F.S.; DUARTE, A.P.; NUSSIO, L.G. et al. Características agronômicas e bromatológicas de híbridos de milho para produção de silagem. Revista Brasileira de Zootecnia, v.38, n.3, p.411-417, 2009.

PEREIRA, E.S.; MIZUBUTI, I.Y.; PINHEIRO, S.M. et al. Avaliação da qualidade nutricional de silagens de milho (Zea mays, L). Revista Caatinga, v.20, n.3, p.8-12, 2007.

PEREIRA, M.N.; Von PINHO, R.G.; BRUNO, R.G.S. et al. Ruminal degradability of hard or soft texture corn grain at three maturity stages. Scientia Agricola, v.61, n.4, p.358-363, 2004.

RIBAS, M.N.; GONÇALVES, L.C.; IBRAHIM, G.H.F. et al. Consumo e digestibilidade aparente de silagens de milho com diferentes graus de vitreosidade no grão. Revista Brasileira de Milho e Sorgo, v.6, n.1, p.104-115, 2007.

RODRIGUEZ, N.M.; SALIBA, E.O.S.; GUIMARÃES JÚNIOR, R. Uso de indicadores para estimativa de consumo a pasto e digestibilidade. Revista Brasileira de Zootecnia, v.35, n.2, p.323-352, 2006

ROSA, J.R.P.; SILVA, J.H.S.; RESTLE, J. et al. Avaliação do comportamento agronômico da planta e valor nutritivo da silagem de diferentes híbridos de milho (Zea mays, L.). Revista Brasileira de Zootecnia, v.33, n.2, p.302-312, 2004.

SENGER, C.C.D.; MÜHLBACH, P.R.F.; SÁNCHEZ, L.M.B. et al. Composição química e digestibilidade 'in vitro' de silagens de milho com distintos teores de umidade e níveis de compactação. Ciência Rural, v.35, n.6, p.1393-1399, 2005.

SILVA, D.J.; QUEIROZ, A.C. Análise de alimentos: métodos químicos e biológicos. 3.ed. Viçosa, MG: UFV, 2002. 235p.

SILVA, J.F.C.; LEÃO, M.I. Fundamentos de nutrição dos ruminantes. Piracicaba: Livroceres, 1979. 380p.

SNIFFEN, C.J.; O’CONNOR, J.D.; Van SOEST, P.J. et al. A net carbohydrate and protein system for evaluating cattle diets: II. Carbohydrate and protein availability. Journal Animal Science, v.70, n.11, p.3562-3577, 1992.

STATISTICAL ANALYSIS SYSTEM - SAS. SAS/STAT ${ }^{\circledR}$ user's guide. Version 9.1. Cary: 2004. 5121p.

VALADARES FILHO, S.C.; MAGALHÃES, K.A.; ROCHA JÚNIOR, V.R. et al. Tabelas brasileiras de composição de alimentos para bovinos. CQBAL 2.0. Viçosa, MG: Universidade Federal de Viçosa, 2006. 297p.

VAN SOEST, P.J.; ROBERTSON, J.B.; LEWIS, B.A. Methods for extraction fiber, neutral detergent fiber and non-starch polysaccarides in relation to animal nutrition cows. Journal of Dairy Science, v.74, n.10, p.3583-3597, 1991.

VAN SOEST, P.J. Nutritional ecology of the ruminant. 2.ed Ithaca: Cornell University, 1994. 476p.

VRANIC, M.; KNEZEVIC, M.; BOSNJAK, K. et al. Effects of replacing grass silage harvested at two maturity stages with maize silage in the ration upon the intake, digestibility and $\mathrm{N}$ retention in wether sheep. Livestock Science, v.114, p.84-92, 2008. 